\title{
表面化学分析に関わる用語解説（TASSA のたまご） 第 7 回
}

TASSA-Vocabulary-094t

英用語 : X-ray photoelectron spectroscopy, XPS

和用語 : $X$ 線光電子分光法, XPS

定 義：X 線が照射された表面から放出される光 電子及びオージェ電子のエネルギー分布 を電子分光器によって測定する方法.

解 説：光を試料に照射した際に光電効果で試料 表面から放出される電子の運動エネル ギ一分布を測定することにより，物質内 の電子状態を調べる手法のことを光電子 分光法という。 その内, $X$ 線を励起光と して用いるものを $\mathrm{X}$ 線光電子分光法 (XPS) という.

(a)

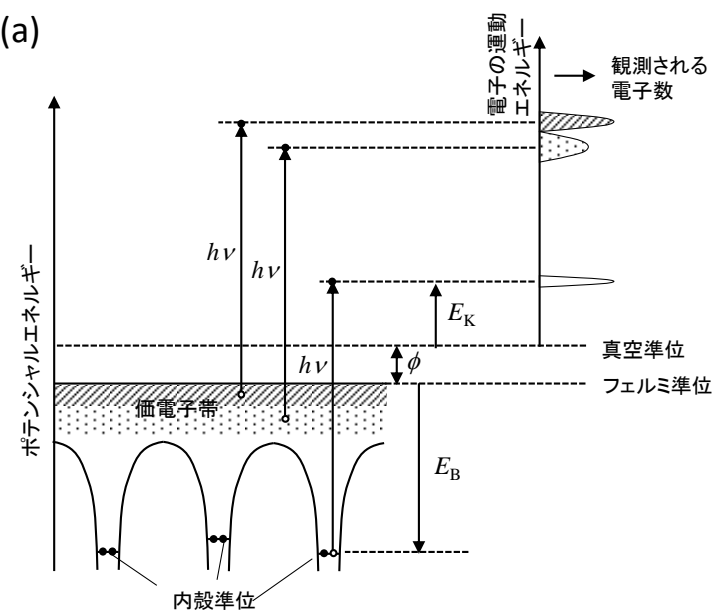

(b)

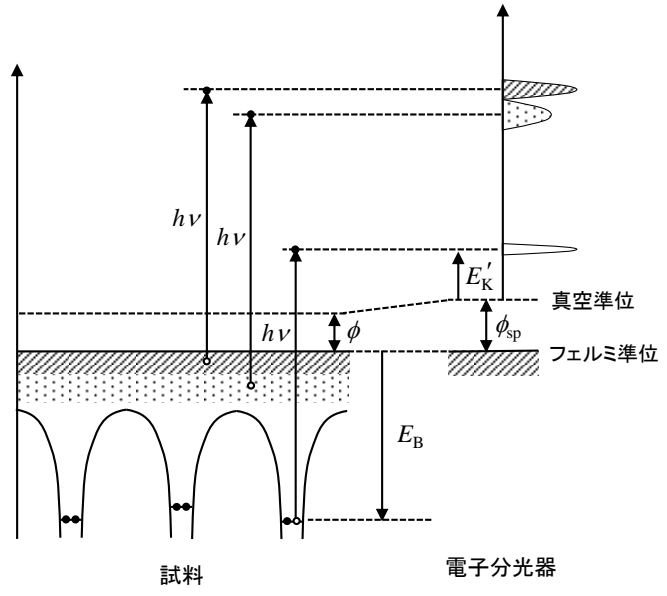

図 1. XPS の原理.
標準化活動部会

測定は超高真空（10-6 $\mathrm{Pa}$ 以下）に保た れた測定装置内に試料を導入して行う. 励起 $\mathrm{X}$ 線光源としては, $\mathrm{Al} \mathrm{K} \alpha$ 線（ $h v=$ $1486.6 \mathrm{eV}$ ) と $\mathrm{Mg} \mathrm{K} \alpha$ 線（同 $1253.6 \mathrm{eV}$ ) の二つの特性 X 線が利用可能なデュアル ターゲット型の X 線管や， $\mathrm{X}$ 線管から発 生した $\mathrm{Al} \mathrm{K \alpha}$ 線をさらにモノクロメータ に通してバンド幅を狭めた単色化 X 線源 を用いることが多いが. 他の元素の特性 $\mathrm{X}$ 線が利用可能な $\mathrm{X}$ 線管や, シンクロ卜 ロン光を励起光源として用いる場合もあ る。電子の運動エネルギーは，入射レン ズ系, エネルギー分析器（静電半球型が 一般的）及び検出系からなる, 電子分光 器により行う。試料位置や姿勢は試料マ ニピュレータにより調整可能で，これに より $\mathrm{X}$ 線の照射位置や入射角, 及び光電 子の検出角を調整する。測定装置には, その他，試料帯電中和用の中和銃や，試 料表面のクリーニング及び深さ方向分析 用のイオン銃などが装備されている.

XPS における光電子発生の原理模式困 を図 1(a)に示す。試料が固体の場合，発 生する光電子の運動エネルギー $E_{\mathrm{K}}$ と, 入 射 $\mathrm{X}$ 線のエネルギー $h v$ と，フェルミ準位 基準の電子の束縛エネルギー $E_{\mathrm{B}}$ との間に は，次式の関係がある[1].

$$
E_{\mathrm{K}}=h v-E_{\mathrm{B}}-\phi
$$

ここで， $\phi$ は試料の仕事関数である. 現実 には光電子の運動エネルギーは電子分光 器で観測するが, 通常, 試料と電子分光 器の基準電位はともに接地されるので, 試料と電子分光器のフェルミ準位が揃う。 そのため，固体の XPS の場合，物質間の 比較がしやすいフェルミ準位を通常は基 準に取る. 電子分光器で観測される光電 子の運動エネルギー $E_{\mathrm{K}}{ }^{\prime}$ は 


$$
E_{\mathrm{K}}{ }^{\prime}=h v-E_{\mathrm{B}}-\phi_{\mathrm{sp}}
$$

となる[2]. ここで, $\phi_{\mathrm{sp}}$ は電子分光器の仕 事関数である。

光電子ピークは各元素に固有な束縛エ ネルギー位置の付近に観測される。この ことを利用して, 試料表面に存在する元 素の同定ができる.さらに, 各元素の電 子準位に対する光電子放出感度を考慮す れば，元素組成の分析も可能である. 実 用的には，ある基準物質の光電子ピーク 強度に対する注目する元素の光電子ピー ク強度比を利用寸る, 相対感度係数法が 用いられることが多い. 相対感度係数は, 実際に測定を行う装置で元素組成既知の 試料を自分で測定することにより求める ことができるが，装置メーカーが提供す る相対感度係数表を用いたり, イオン化 断面積などの理論值を用いたりするなど の方法もある。

ある元素の同じ電子準位であっても， 詳細にみると, その元素が置かれた化学 環境の違いでその元素の電子状態が変化 寸ることにより，束縛エネルギーが少し だけ変化する (最大数 $\mathrm{eV}$ 程度)。この束 縛エネルギーの変化のことを化学シフト という。これまでに膨大な化合物の化学 シフト值がまとめられており[3-6], これ らのデータと測定した束縛エネルギーと を比較することにより，注目する元素の 化学（電子）状態を推定することができ る.

金属の様な電気伝導性が高い物質では, 電子分光器との電気的接触を取ることに より正確な束縛エネルギーを求めること ができる。しかし, 絶縁体の様に電気伝 導性に乏しい物質では, 光電子の放出で 測定試料表面が正に帯電することにより， 光電子ピークが低運動エネルギー側にシ フトし束縛エネルギーが見かけ上高くな る場合がある。この効果のことを試料帯 電（あるいはチャージアップ）という。 このような場合は，低エネルギーの電子 やイオンを試料表面に照射し, 試料帯電 を中和する必要がある。しかし，完全な 帯電中和は現実的には困難であるため,
試料中のある特定の元素のピークを参照 することにより帯電補正を行う。帯電補 正の方法には，污染炭化水素化合物（空 気に試料が触れると必ず試料表面に存在 する)の C 1s ピークを基準とする方法や, 試料表面に金を微量に蒸着し $\mathrm{Au}$ 4f ピー クなどの金の内殼ピークを基準とする方 法，あるいは内部標準を用いる方法等が 提案されている[7].

XPS スペクトルには, 光電子ピークの 他, 光電子放出により生成した内殼励起 状態の緩和の一過程として試料から放出 されるオージェ電子によるピークも検出 される.オージェピークは注目元素に固 有の運動エネルギー位置の付近に観測さ れる. オージェピークも注目元素の化学 状態の違いによる化学シフトを示すため, 光電子ピークと同様に状態分析に用いる ことができる. また, 光電子ピークの運 動エネルギーとオージェピークの運動エ ネルギーの和（オージェパラメータ）が 化学状態に特有な值を示すことを状態分 析に利用する方法もある[8].

光電子ピークやオージェピークの他に サテライトピーク（前 2 者以外のピーク の総称）も検出される. サテライトピー クにはそれぞれ物理的起源があるので, それらを検討することによりその物質の 化学 (電子) 状態を知ることができる[9].

先に述べた通り, XPS では通常 $\mathrm{Al} \mathrm{K} \alpha$ 線や $\mathrm{Mg} \mathrm{K} \alpha$ 線といった $1.5 \mathrm{keV}$ 以下の軟 $\mathrm{X}$ 線を励起 X 線として用いるため, 観測 される電子の運動エネルギーも $1.5 \mathrm{keV}$ 以下となる. 固体試料の場合, 試料に入 射するX X 線の侵入深さに比べて, 試料内 部で発生した光電子の脱出深さの方がは るかに浅く, XPS の分析深さはほぼ後者 で決まる．後者の指標として物質内にお ける電子の非弾性平均自由行程（inelastic mean free path, IMFP) があるが, $1.5 \mathrm{keV}$ 以下の電子の IMFP は物質により差があ るが最大数 $\mathrm{nm}$ 程度である.つまり, 通常 の XPS では表面からせいぜい数 $\mathrm{nm}$ 程度 の深さを分析していることになる.

この特性を利用して, 深さ方向に濃度 分布のある試料や多層膜試料の場合, イ 
オンビームにより原子レベルで少しずつ 掘削しながら XPS 分析を行うことにより， 深さ方向の元素分布を知ることができる (イオンスパッタリング法)。ただし，イ オン照射による試料の損傷や選択スパッ タリングが生じることもあるため, 化合 物の深さ方向分布を測定する際には注意 を要する.イオンビームの種類としては,

(単原子) アルゴンイオンが一般的だが, $\mathrm{C}_{60}$ イオンビームや, 数千個のアルゴンな ぞのガス原子 (分子) から形成されるガ スクラスターイオンビームを用いる, 試 料損傷が少ないイオンスパッタリング法 も近年普及してきている.

XPS 分析で微小部を分析する方法には, 照射 X 線を絞る方法と, 電子レンズによ り放出された光電子の取り込みを視野制 限する方法がある. また, 近年の XPS に よる微小部の分析技術の向上により, 数 ミクロンのオーダーの分析や元素や化合 物のマッピングも可能となった.

上述の通り, 通常のXPS で使用寸る励 起光は $1.5 \mathrm{keV}$ 以下の軟 $\mathrm{X}$ 線領域の光で あるが，3〜4 keV 以上の X 線を励起光と して用いる硬 X 線光電子分光法 (HX-PES あるいは HAXPES などと呼ばれる）の利 用も，2000 年以降実用的に可能となった [10]. 当初 HAXPES は SPring-8 をはじめ とする高輝度シンクロトロン光が利用可 能なシンクロトロン光施設においてのみ 可能であったが, 最近, $\mathrm{Ag} \mathrm{L} \alpha$ 線 (3.0 keV), $\mathrm{Cr} \mathrm{K} \alpha$ 線 $(5.4 \mathrm{keV}) ， \mathrm{Ga} \mathrm{K} \alpha$ 線 $(9.3 \mathrm{keV})$ といった高いエネルギーを持つ特性 X 線 を利用可能な X 線管を備えた市販装置も 登場し, 実験室でも HAXPES が可能に なってきた. HAXPES では通常のXPS よ り高いエネルギーをもつ X 線を励起光と して用いるため, 光電子の運動エネル ギーが高くなり物質中での電子の非弾性 平均自由行程 IMFP が長くなるため, 分 析深さが通常の XPS に比べて梁くなる [11]. 通常のXPS では分析が困難な深い 領域の電子状態の分析が可能であること が HAXPES の最大の特徵である. 具体的 な分析深さは, 励起光のエネルギー, 分 析対象物質及び電子準位によるが，例え
ば $\mathrm{SiO}_{2}$ の $\mathrm{Si} 2 \mathrm{p}$ 準位を通常の $\mathrm{Al} \mathrm{K \alpha}$ 線 $(\sim 1.5 \mathrm{keV})$ によるXPS と HAXPES（8 $\mathrm{keV})$ で分析する場合の非弾性平均自由行 程 IMFP を計算すると, それぞれ $3.8 \mathrm{~nm}$ と $15.7 \mathrm{~nm}$ となり [12], 通常の XPS に比べ て HAXPES の分析深さは 4 倍程度になる。 この深い分析深さを生かして, 例えば電 子デバイスにおける電極下に埋もれた電 極／半導体界面近傍の電子状態の分析等 に HAXPES は利用されている。 また, 通 常の X 線源では励起できない深い準位の 電子も励起可能であるため, 測定対象元 素が複数ありピークが重畳する場合に, 通常のXPS では励起できない深い準位を 選択してピークの重畳を避けることがで きるなど，分析の自由度が高まるという 利点も HAXPES にはある。

参考文献：

[ 1] 田沼繁夫, $X$ 線光電子分光法, 日本表 面科学会編, 2.1 節, pp. 5 6, 丸善出版 (1998)

[ 2] 吉原一紘, J. Vac. Soc. Jpn. 56, 153 (2013).

[ 3] J. F. Moulder, W. F. Stickle, P. E. Sobol, K. D. Bomben, Handbook of X-ray photoelectron Spectroscopy, Phys. Electronics, Minnesota (1992).

[ 4] N. Ikeo, Y. Iijima, N. Niimura, M. Shigematsu, T. Tazawa, S. Matsumoto, K. Kojima, and Y. Nagasawa. Handbook of $X$-ray photoelectron Spectroscopy, JEOL, Akishima (1991).

[ 5] D. Briggs and M. P. Seah, Practical Surface Analysis, vol.1-Auger and X-ray Photoelectron Spectroscopy, John Wiley \& Sons, (1990).

[ 6] NIST X-ray Photoelectron Spectroscopy Database, NIST Standard Reference Database Number 20, National Institute of Standards and Technology, Gaithersburg MD, 20899 (2000), doi:10.18434/T4T88K, (retrieved Aug. 2, 2019).

[ 7]田中浩三, $X$ 線光電子分光法, 日本表 面科学会編, 5.4.4 節, pp. 91 92, 丸善出版 (1998). 
[ 8] 名越正泰, $X$ 線光電子分光法, 日本表 面科学会編, 7.1.2 節, pp. 137 140, 丸善出 版 (1998).

[ 9] 名越正泰, $X$ 線光電子分光法, 日本表 面科学会編, 7.2 節, pp. 147 158, 丸善出 版 (1998).

[10] K. Kobayashi, Nucl. Instrum. Methods Phys. Res. A 601, 32 (2009).

[11] HAXPES で分析深さが深いというの は, 通常のXPS の場合に比べて, 全光電 子信号に含まれる表面からの寄与の割合 が小さく深部からの寄与の割合が大きい ということであり, 深部だけを分析でき るというわけではないことに注意された い.

[12] QUASES-IMFP-TPP2M Ver. 3.0, Inelastic electron mean free paths calculated from the TPP-2M formula. S. Tanuma, C. J. Powell, and D. R. Penn, Surf. Interface Anal. 21, 165 (1994).

執筆者 陰地 宏 查読者 牧野 久雄 